Until adequate procedural legislation is passed, whether for the enforcement of specific offences or of universal application in the case of a corporate accused, the situation will remain, at best, confused.

-N. C. WrtTManN*

- B.Comm., LL.B. (Alta.) of the 1967 graduating class.

\title{
LABOUR DISPUTES - INTERIM INJUNCTION - UNDERTAKING FOR DAMAGES-VIEWEGER CONSTRUCTION CO. LTD. v. RUSH \& TOMPKINS CONSTRUCTION LTD.
}

The interlocutory injunction is a powerful weapon in the hands of the person enjoying its benefit. It issues before the final determination of the rights of the parties involved and thus runs the risk of treading upon the right of the person against whom its issues-should his right ultimately prevail at trial. It is the purpose of this comment to discuss the respective rights of the parties to an interlocutory injunction and to illustrate the effect of the $\mathbf{1 9 6 5}$ decision of the Supreme Court of Canada in Vieweger Construction Co. Ltd. v. Rush \& Tompkins' on the defendant's right to compensation.

It is of significance to note the dilemma of the defendant against whom the injunction issues. The injunction is a strong remedy, acquiring strength through its method of enforcement. Failure to obey the injunction results in criminal sanctions, yet the normal safeguards afforded by the law are not present at its issuance. The injunction is granted on affidavit evidence, there is no opportunity for cross-examination or careful sifting of the facts, the truth of either side is difficult to ascertain, and in fact, there is not a final determination of the rights. Still the defendant must act in accordance with the injunction. How then can he be compensated for damage resulting to him from the operation of the injunction where the final determination of the rights is in his favour? Apart from the undertaking for damages which accompanies an application for an interim injunction he has little recourse to receive compensation. It is therefore of utmost importance to know the extent and scope which has been attributed to the undertaking.

Whether or not an inquiry as to damages will be directed is at the discretion of the court.

The undertaking usually inserted in an interim injunction order is one not to the party, but to the Court to pay damages if the Court should be of the opinion that under the circumstances the plaintiff ought to pay damages, and puts himself in the power of the Court for that purpose independently of the suit."

As with every equitable discretion, such discretion is not unlimited but adheres closely to principles which have been established as guide posts to its exercise. What then, are the principles upon which a court will exercise its discretion in favour of the defendant? 
Alberta's position prior to 1965 is best illustrated by principles laid down in McBrantney v. Sexsmith. ${ }^{3}$ Hyndman, J. stated:

The law is well settled that it does not follow that because an interlocutory injunction is dissolved before or after trial the successful defendant is therefore or in any event, entitled to damages. The test is whether the plaintiff, by the suppression of facts, or misrepresentation, or maliciously, improperly obtains the injunction. 4

He goes on to state:

The awarding of damages then is within the discretion of the court. But I also take it to be the law that the discretion will be exercised only in case the issuance of the injunction or order was wrongful in the sense that it was prompted by malice or was without reasonable and probable cause or where the terms of the order were such that the party defendant could not reasonably be expected to act under it in such a way as to avoid damages. All the surrounding facts and circumstances must be examined.s

A close examination of these principles indicates that the ultimate determination on the merits is not a prime consideration in deciding whether or not to award damages. The test to be applied is not "Did the applicant have an absolute right upon which to base his interlocutory injunction?" but "Was he bona fide in asking for it in the first instance? Did he have a prima facie case without the suppression or misrepresentation of facts?"

There have emerged through the case law two distinct trends of thought regarding the reason for the requirement of the undertaking and its effect. One line of cases, including McBrantney v. Sexsmith, ${ }^{6}$ relied on the 1882 English case Smith v. Day;" although much of what has been relied on was said by way of obiter. Jessel, M. R. in Smith v. $D a y^{s}$ placed emphasis on the need for plaintiff default in applying for the interlocutory injunction before awarding damages. Of particular interest are the statements made by the Master of the Rolls with regard to the history and object of the insertion of the undertaking.

It was originally inserted only in ex parte orders for injunctions. Its object was, so to say, to protect the court as well as the defendant from improper applications for injunctions. If the evidence supposed or misrepresented facts the court was enabled not only to punish the plaintiff but compensate the defendant. By degrees the practise was extended to all cases of interlocutory injunctions. The reason for this extension was that though when the application was disposed of upon notice, there was not the same opportunity for concealment or misrepresentation, still, owing to shortness of time allowed, it was often difficult for defendant to get his case properly, and as the evidence was taken by affidavit and generally without cross-examination, it was impossible to be certain on which side the truth lay. The court therefore required the undertaking in order that it might be able to do justice if it had been induced to grant the injunction by false statement or suppression. I am of the opinion that the undertaking was not intended to apply where the injunction was wrongly granted, owing to the mistake of the court, as for instance if the Judge was wrong in his law. I think this is shown by the fact that such an undertaking is never inserted in a final order for an injunction."

The above quotation indicates that there was a recognition of the ease with which facts could be misrepresented or surpressed, and a corresponding recognition of the defendant's lack of recovery of damage where

\& Ibid. This case followed statements made in the earlier Alberta decision Albertson v. Secord (1912), I D.L.R. 804, 4 Alta. L.R. 90.

I Id., at 87-88.

5 Id., at 88.

6 Supra, at $n .2$.

7 (1882), 21 Ch. D. 421

8 Ibid.

8 Id., at 425. 
this occurred. If, indeed, the sole purpose of the undertaking is to protect against misrepresented facts and ensure the best evidence possible under the circumstances, it would appear the plaintiff could not be held liable on his undertaking without some default on his part. In exercising its discretion the court looks to the correct issuance of the injunction in the first instance. Under this view stress is given to the need for a remedy for the applicant who stands in fear of suffering irreparable damage. The prima facie case which he has, emerges as a sufficient right upon which to enjoy the benefits of an interlocutory injunction even though the ultimate right lies with the defendant.

Griffith v. Blake'0 has emerged as the locus classicus of another view-a view which feels the object of the undertaking is the protection of the defendant who succeeds on the merits. In this case Cotton, L. J., who dissented with the views of the Master of the Rolls in Smith v. Day," was given an opportunity to expressly disapprove the dictum. His disapproval has been adopted as a correct expression of the law of England as it now stands.

An undertaking as to damages remains in force notwithstanding dismissal of an action or its discontinuance and when the plaintiff ultimately fails on the merits the defendant is entitled to an inquiry as to damages sustained by reason of the interim injunction, unless there are special circumstances. The undertaking applies, even though the plaintiff has not been guilty of misrepresentation, suppression, or other default in obtaining the injunction and is equally enforceable, whether the mistake in granting the injunction was in point of law or in point of fact. ":

Notice is taken of the fact that in granting an interim injunction a judge does not purport to conclude a right; and a mistake on his part does not relieve the plaintiff of his undertaking to compensate. Recognition is given to the interference with a right which is of such a nature as should be free from interference. Thus, under this view the undertaking becomes the price the plaintiff has to pay for the benefit he has received from the injunction should he lose at trial. He runs the risk that although he may have a prima facie right, he may not have a right which entitles him to this remedy.

The trend of thought above is comparable to American jurisprudence in this area. The American practice involves the giving of a bond as security for the injunction. It has been stated that prior to this requirement, the person restrained had no relief where the injunction was subsequently dissolved as issuing without just cause unless he could establish that the injunction was sued out maliciously and without probable cause. The bond was evolved to remedy this situation and to provide compensation for interference with an ultimate right. ${ }^{13}$

Vieweger Construction Co. Ltd. v. Rush \& Tompkins Construction Ltd." has had an effect on the former Alberta position, the law now adhering closely to that adopted by the United States and England.

in (1884), $27 \mathrm{Ch}$. D. 474. An adoption of a simllar line of reasoning to that used in Griffith v. Blake has been shown in Graham v. Campbell, (1877), 7 Ch.D. 470, L. J. Ch. 593. 38 L.T. 195. 26 W. R. 336, and Hunt v. Hunt.

11 Supra, at n. 7.

1228 Halsbury's Law of England, (3rd Ed.), adopling a statement In Griffith v. Blake.

1328 American Jurisprudence, 434. It is of interest to note that the American bond system does not go as far towards compensation automatically as does the Engish view, in that if the amount on the bond fails to adequately cover damages incurred it is necessary to prove malice and want of probable cause for the remainder. 43 Corpess Juris Secundum 1055.

14 Supre, at n. 1. 
The facts relevant to this comment may be stated briefly. On October 13, 1959, Rush \& Tompkins Construction Ltd. applied for and received an interim injunction restraining the appellant company from removing construction equipment from their use. There was no misrepresentation or suppression of facts and the usual undertaking for damages was entered into. The appellant moved to vacate the order but such order was refused. At trial on the merits, judgment was entered for the defendant, but Riley, J. refused to award damage for the loss of profits the defendant had suffered during the months he was deprived of the use of the equipment. McBrantney v. Sexsmith ${ }^{15}$ was applied and followed. In 1964 the Supreme Court of Alberta, Appellate Division, 10 reversed the trial decision on the merits and thus Rush \& Tompkins Construction Ltd. was relieved of its undertaking. In the Supreme Court of Canada, judgment delivered by Spence, J., the decision of the Appellate Division was reversed and once more the question regarding damages arose for determination.

The Supreme Court disapproved McBrantney v. Sexsmith ${ }^{13}$ and adopted the following quotation from Griffith v. Blake ${ }^{1 s}$ as the proper test to be applied.

Whenever an undertaking is given and the plaintiff ultimately fails on the merits, an inquiry as to damages will be granted unless there are special circumstances to the contrary.11

Counsel argued that even accepting the above statement special circumstances did exist. He contended that where the injunction issued due to a mistake of law, as evidenced by the fact that three judges in the Court of Appeal were of the opinion that the respondent company was entitled to it, and where there was no misrepresentation or perjury special circumstances are constituted. In handling this contention it is stated by Spence, J.:

I am of the opinion that these circumstances do not constitute such "special circumstances" as were in the mind of Cotton, L. J. There are examples of plaintiffs who are public bodies and who acted in the public interest to hold the stituation in status quo until the rights were determined. There are other cases where the defendant, though he succeeded upon technical grounds, certainly had been guilty of conduct which did not move the court to exercise its discretion in his favour. In these cases, the Court has found the "special circumstances" which entitled it to refuse a reference as to damages.

Spence, J. was speaking with great accuracy when he says that the special circumstances outlined by counsel were not those in the mind of Cotton, L. J., for it must be remembered that in making his statement he was expressing a view directly opposed to the need for plaintiff default.

Thus Vieweger Construction Co. Ltd. v. Rush \& Tompkins Ltd. ${ }^{20}$ has come forth stressing the importance of the decision on the merits. It is suggested that this decision has remedied an inadequacy in our law in relation to protection of defendant rights on an interlocutory injunction. It takes cognizance of the fact that such an injunction does

is Supra, at n. 2.

16 Rush \& Tompkins Construction Ltd. v. Vieweger Construction Co., (1964), 45 D.L.R. (2d) 122

17 Supra, at n. 2.

is Supra, at n. 10, 477.

19 Supra, at n. 1., 519 .

20 Supra, at n. 1. 
not purport to conclude a right but merely maintains matters in status quo until a hearing," infringed. This decision also appears to fall into place with other principles which the Court observes in exercising its discretion as to whether or not to grant an injunction. A court may withhold an injunction upon the undertaking of the defendant to compensate the plaintiff if he ultimately has the legal right. Should not the converse situation be the same?"?

It is easy to observe the necessity for the recent decision and its resulting benefits but one must also be aware of the possibility of resulting harms-the plaintiff too has a right at stake. He has a prima facie case and if forced to await trial on the merits may suffer irreparable damage; damage which by definition cannot adequately be compensated. The Courts of Equity developed the remedy of the interlocutory injunction to protect against the occurrence of such damage. ${ }^{23}$ Will the effect of Vieweger Construction Co. Ltd. v. Rush \& Tompkins Construction Ltd..$^{2-1}$ weaken this protection? It is suggested that in fact it will. One can readily see that the plaintiff who ultimately has no right must pay for the benefit. he has received from the injunction; for when there is no right one is not entitled to enjoy a remedy. However, what of the man who has a right, but realizes he cannot predict with certainty the final determination? Will he not fear asking for protection in the first instance? He realizes that by applying he takes the risk of compensating should he lose at trial, and though the risk may be small, where the compensation will be large fear of losing may prevent application. Thus, although the new law may prevent unsupported applications it will also prevent applications where the ultimate right exists. As a result, persons will suffer irreparable damage which cannot adequately be compensated; the very thing the courts hoped the interlocutory injunction would prevent. Perhaps it was a realization of the plaintiffs dilemma which led to statements like the following:

The plaintiff is not wrong in coming to this court and it would be monstrous that he should be made to bear all the costs and damages incident to a litigation which the court thought he was right in instituting though he did not succeed.25

Surely the right to protection is recognized, yet where the damages will be large the cautious man has been burdened with the onus of determining in his own mind what the highest court will decide; a predictability which does not always exist in our law.

Keeping in mind that Vieweger Construction Co. Ltd. v. Rush \& Tompkins Construction Ltd."2i will result in persons being more certain of their rights before applying, it is suggested that the concept of no default on the part of the defendant should be applied strictly. Spence, J. outlined such default as one of the "special circumstances" which would entitle the plaintiff to relief on his undertaking. The defendant should

21 Kerr on Injunctions, Fifth Ed., 2.

2s Damage which cannot adequately be compensated by money lies at the root of equitable remedies, and indeed need be shown to obtain an injunction. Kerr. Supra, $n$. 21 . discusses irreparable damage at page 29.

24 Supra, at n. 1.

2: Bingley v. Marshall, 11 W.R. 1018, 9 L.T.. (N.S.) 144. Smith v. Day also seemed to recognize the dilemma of the plaintiff and the need for predictability in that a distinction was drawn between strong cases and those of reasonable doubt.

20 Supra, at $\mathrm{n} .1$. 
not be allowed to hold back any facts which are quite material to the decision and still be allowed to come forward and claim compensation, as these facts will be material to the plaintiff's decision to obtain or continue the interlocutory injunction. ${ }^{2 i}$

Thus the interlocutory injunction is an unique remedy, issuing before the conclusion of the right upon which it is based. The remedy has arisen due to the inability of the judicial process to conclude the right in time to prevent irreparable damage ${ }^{--}$However, it is necessary to point out that the inability to compensate adequately for injury incurred is not infrequent in the law; and although unfortunate, does not of itself justify interference with another man's rights. Unlike most remedies, which issue to correct a wrong which has already occurred, the injunction issues to prevent the occurrence or continuance of the wrong. Surely it is encouraging to see positive steps in the form of preventive law, but this is not so where a remedy like the interlocutory injunction is allowed to do damage where the basic reason for its existance (the plaintiff's right) does not, in fact, exist.

In conclusion, it is submitted that the existence of the interlocutory injunction is commendable, but those seeking its benefit do so at their own risk. As stated by James, L. J. in Graham v. Campbell:

If any damage has been occasioned by an interlocutory injunction, which, on the hearing is found to have been wrongly asked for, justice requires that such damage should fall on the voluntary litigant who fails, not on the litigant who has been without just cause made so.:":1

Hopefully the plaintiff's rights can receive increased protection through alleviation of some of the risk involved by increased certainty and predictability in the law; although absolute certainty will never be achieved if law is to keep pace with social change. Thus, it is felt that Vieweger Construction Co. Ltd. v. Rush \& Tompkins Construction Ltd. ${ }^{\text {so }}$ has brought a desirable change to the law of Alberta and, although it may be said absolute justice does not exist, certainly the case has left the law more just.

-Carole Smallwood*

'i Montreal Street Railuay Co. v. Ritchie (1889), 16 S.C.R. 622 felt that where a party had notice of an application for the issue of a writ of injunction and did not chose to repudiate he brings any damage suffered on himself.

2. When the interlocutory injunction first devcloped. the time factor was extremely more important in that it took longer to obtain a hearing of the merits.

3u Supra, at n. 10.

\#i) Supra, at n. 1.

B.A., LL.B. (Alta.) of the 1967 graduating class.

MORTGAGES-LAND MORTGAGE_PERSONAL GUARANTEE OF DEBT-COLLATERAL CHATTEL MORTGAGE_PROTECTION GIVEN TO PURCHASERS AND MORTGAGORS BY JUDICATURE ACT, S.A. 1964, C.40, S.34(17)-CREDIT FONCIER FRANCO-CANADIAN v. EDMONTON AIRPORT HOTEL CO. LTD. and SUPERSTEIN.

The case of Credit Foncier Franco-Canadian v. Edmonton Airport Hotel Co. Ltd. and Superstein ${ }^{1}$ and the resulting amendment to The

1 (1965) S.C.R. 441, affirming (1964), 48 W.W.R. 641, (1965), 47 D.L.R. (2d) 508 (Alta. C.A.), varying (1964), 43 D.L.R. (2d) 174. 